\title{
The Inducible Amine Dehydrogenase in Pseudomonas putida NP and its Role in the Metabolism of Benzylamine
}

\author{
By D. R. DURHAM AND J. J. PERRY \\ Department of Microbiology, North Carolina State University, \\ Raleigh, North Carolina 27607, U.S.A.
}

(Received 23 September 1977; revised 31 October 1977)

\begin{abstract}
Pseudomonas putida NP utilizes benzylamine and other primary amines as the sole source of carbon, nitrogen and energy. Extracts of organisms grown on benzylamine and other amines contained an inducible amine dehydrogenase [amine:(acceptor) oxidoreductase (deaminating)]. The enzyme required either phenazine methosulphate, 2,6-dichlorophenolindophenol, ferricyanide or cytochrome $c$ for activity; oxygen, FAD, FMN, NAD ${ }^{+}$and $\mathrm{NADP}^{+}$were not utilized. The substrate specificity of the amine dehydrogenase was independent of the amine utilized for growth; when cell-free extracts of organisms grown on benzylamine, $n$-propylamine or $n$-butylamine were subjected to polyacrylamide gel electrophoresis, a single band of enzymic activity was detected in an equivalent position in each gel. This indicated that an enzyme of broad specificity was involved in the deamination of these substrates. The amine dehydrogenase was heat labile; $97 \%$ of the initial activity was lost after incubation at $65^{\circ} \mathrm{C}$ for $3 \mathrm{~min}$. By isolating intermediates and demonstrating the requisite enzyme activities, it was shown that benzylamine was deaminated to benzaldehyde and further metabolized through benzoate and via the meta (or $\alpha$-keto acid) pathway.
\end{abstract}

\section{INTRODUCTION}

Microbial enzymes which oxidatively cleave alkyl-nitrogen bonds of primary mono- and diamines fall into two categories: oxidases and dehydrogenases. Amine oxidases transfer electrons from the prosthetic group directly to oxygen to form $\mathrm{H}_{2} \mathrm{O}_{2}$, while an alternative electron acceptor such as phenazine methosulphate (PMS) or cytochrome $c$ functions as the immediate electron acceptor for amine dehydrogenases. There are numerous accounts of amine oxidases in bacteria (Bachrach, 1973; Kapeller-Adler, 1970; Large, 1971), but few primary monoamine dehydrogenases have been reported (Blevins \& Perry, 1972; Cerniglia \& Perry, 1975; Dahl, Mehta \& Hoare, 1972; Eady \& Large, 1968; Mehta, 1977). Eady \& Large (1968) purified and characterized an amine dehydrogenase that was induced in Pseudomonas AM1 during growth on methylamine and this enzyme oxidized methylamine to formaldehyde in the presence of either PMS, cytochrome $c$, ferricyanide, brilliant cresyl blue or 2,6-dichlorophenolindophenol (DCPIP). The enzyme had a high affinity for primary mono- and diamines, but little or no activity for isoamines. Recently, Cerniglia \& Perry (1975) isolated a strain of Mycobacterium convolutum by soil enrichment on $n$-propylamine; this strain also metabolized isopropylamine. Although it was shown that these amines were metabolized via divergent pathways, their initial oxidative deamination was catalysed by a non-specific amine dehydrogenase.

The ability of pseudomonads to utilize amines is particularly useful for the delineation of the fluorescent group of Pseudomonas: $P$. putida can be distinguished from $P$. aeruginosa and in most cases from $P$. fluorescens by the capacity to assimilate benzylamine (Stanier, 
Palleroni \& Doudoroff, 1966). Although the amine specificities of various Pseudomonas species were reported by Stanier et al. (1966) and Ballard et al. (1970), data for the characterization and metabolic studies of the enzymes responsible are lacking. This investigation was initiated to examine the degradation of amines by $P$. putida and to determine the nature of the enzyme responsible for the initial oxidative cleavage of primary amines.

\section{METHODS}

Organism. Pseudomonas putida NP was isolated by enrichment culture with naphthalene as a sole source of carbon and energy, and was obtained from Dr David T. Gibson, The University of Texas, Austin, U.S.A. This organism conforms to biotype A as it cannot grow on L-tryptophan, D-galactose or nicotinic acid. Stock cultures were maintained on nutrient agar slants and stored at $4{ }^{\circ} \mathrm{C}$.

Media and growth conditions. Pseudomonas putida NP was cultured on the mineral salts medium of Leadbetter \& Foster (1958) supplemented with $10 \mathrm{~mm}$-sodium benzoate or sodium succinate as carbon source. Amines were neutralized with $\mathrm{HCl}$, filter sterilized, and added to give a final concentration of $5 \mathrm{~mm}$. Liquid cultures were inoculated with cells pre-adapted to growth on the appropriate substrate (the amine served as both carbon and nitrogen source) and incubated at $28{ }^{\circ} \mathrm{C}$ on a reciprocating shaker at $200 \mathrm{rev} . \mathrm{min}^{-1}$.

Preparation of cell extracts. Cells were grown to late-exponential phase, harvested by centrifuging at $10000 \mathrm{~g}$ at $4{ }^{\circ} \mathrm{C}$ and washed twice with cold $50 \mathrm{~mm}$-sodium phosphate buffer, $\mathrm{pH} 7.0$. Washed cell pastes were resuspended in buffer and disrupted by two passages through a French press at $35 \mathrm{MPa}$. Cell debris was removed by centrifuging at $37000 \mathrm{~g}$ for $30 \mathrm{~min}$ at $4{ }^{\circ} \mathrm{C}$. Crude extracts were prepared by centrifuging the supernatant at $102000 \mathrm{~g}$ for $60 \mathrm{~min}$ in a Beckman L2-65 ultracentrifuge.

Enzyme assays. Amine dehydrogenase activity was determined spectrophotometrically at $24^{\circ} \mathrm{C}$ by measuring the PMS-coupled reduction of DCPIP by the method of Eady \& Large (1968).

The following enzymes were assayed as described by Hegeman (1966) and Feist \& Hegeman (1969): benzaldehyde dehydrogenase (EC 1.2.1.28; benzaldehyde: NAD ${ }^{+}$oxidoreductase), benzyl alcohol dehydrogenase, catechol 1,2-oxygenase [EC 1.13.11.1; catechol:oxygen 1,2-oxidoreductase (decyclizing)] and catechol 2,3-oxygenase [EC 1.13.11.2; catechol:oxygen 2,3-oxidoreductase (decyclizing)].

Protein was determined by the method of Lowry et al. (1951).

Polyacrylamide gel electrophoresis. Disc gel electrophoresis was performed as described by Davis (1964) using $7 \%(\mathrm{w} / \mathrm{v})$ acrylamide gels. The gel and reservoir buffers were prepared according to Laemmli (1970) except that sodium dodecyl sulphate was omitted. Crude extracts were mixed with bromothymol blue in

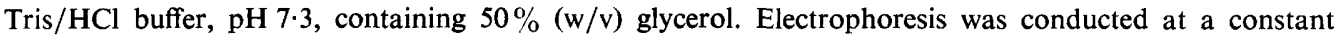
current of $2 \mathrm{~mA}$ per gel at $4{ }^{\circ} \mathrm{C}$ until the tracking dye had migrated through the gel. Amine dehydrogenase activity in gels was located by coupling enzymic activity to the reduction of tetrazolium chloride (Cerniglia \& Perry, 1975).

Other techniques. Manometric techniques were those described by Umbreit, Burris \& Stauffer (1964). Manometric vessels contained (in a total volume of $2.4 \mathrm{ml}$ ) whole cells $(5 \mathrm{mg}$ dry wt) or cell extract $(5.4 \mathrm{mg}$ protein) in $200 \mu \mathrm{mol}$ phosphate buffer $\mathrm{pH} 7 \cdot 0,20 \mu \mathrm{mol}$ substrate and, in the centre well, $0.2 \mathrm{ml} 20 \%(\mathrm{w} / \mathrm{v})$ $\mathrm{KOH}$. For amine dehydrogenase assays, $3 \mu \mathrm{mol} \mathrm{KCN}$ and $1 \mu \mathrm{mol}$ PMS were also added. The incubation temperature was $30^{\circ} \mathrm{C}$. All values were corrected for endogenous respiration. The 2,4-dinitrophenylhydrazones were determined as described previously (Blevins \& Perry, 1972).

\section{RESULTS}

\section{Specificity of $P$. putida for growth on various amines}

Amines used as the sole source of carbon, nitrogen and energy by $P$. putida were limited to $\mathrm{C}_{3}, \mathrm{C}_{4}, \mathrm{C}_{5}$ and $\mathrm{C}_{7}$ primary aliphatic monoamines and the substituted primary amines, benzylamine, ethanolamine and histamine. $n$-Butylamine, benzylamine and $n$-propylamine were the most readily utilized growth substrates with generation times of 60,75 and $130 \mathrm{~min}$, respectively. No growth occurred on methylamine, isopropylamine, 1,2-diaminopropane, sec-butylamine, tert-pentylamine, octylamine, decylamine, tryptamine, tyramine and phenylethylamine.

\section{Acceptor specificity of amine dehydrogenase}

In manometric experiments with cell-free extracts of benzylamine-grown organisms, no oxygen uptake occurred with benzylamine as substrate unless PMS was added. Enzymic 
Table 1. Specific activities of amine dehydrogenase in $P$. putida grown on various amines

Enzymic activity in crude extracts was measured by the standard spectrophotometric assay with the substrate added at $6.6 \mathrm{~mm}$. Specific activities are expressed as $\mu \mathrm{mol}$ DCPIP reduced $\mathrm{min}^{-1}(\mathrm{mg}$ protein $)^{-1}$.

\begin{tabular}{lccc}
$\quad$ & \multicolumn{3}{c}{ Growth substrate } \\
Test substrate & Benzylamine & $\begin{array}{c}n- \\
\text { Propylamine }\end{array}$ \\
Benzylamine & 0.21 & 0.12 & 0.06 \\
n-Butylamine & 0.32 & 0.20 & 0.10 \\
$n$-Propylamine & 0.26 & 0.13 & 0.07 \\
Methylamine & 0.10 & 0.04 & 0.03 \\
1,3-Diaminopropane & 0.05 & 0.02 & 0.02 \\
Ethanolamine & 0.03 & 0.01 & 0.01
\end{tabular}

activity could be measured spectrophotometrically by replacing oxygen with DCPIP. Other electron acceptors included ferricyanide and cytochrome $c$. FAD, FMN, NAD ${ }^{+}$and $\mathrm{NADP}^{+}$could not serve as the initial electron acceptor (Durham \& Perry, 1977).

\section{Induction of amine dehydrogenase activity}

Amine dehydrogenase activity was not detected in cell extracts of benzoate- or succinategrown cells by the standard assay procedure or by gel electrophoresis. Induction of the enzyme by benzylamine was studied by growing the organism for several subcultures on succinate and then using a washed suspension of organisms harvested in mid-exponential growth to inoculate mineral salts medium containing benzylamine. Growth was followed spectrophotometrically at $660 \mathrm{~nm}$; samples were removed periodically, cell-free extracts were prepared and assayed for amine dehydrogenase activity. Initially no enzymic activity was present (Fig. 1), but appreciable levels of amine dehydrogenase activity were detected before growth occurred (after a $5 \mathrm{~h}$ lag phase).

\section{Specificity of amine dehydrogenase}

The specific activities of amine dehydrogenase in crude extracts of $P$. putida NP grown on benzylamine, $n$-propylamine and $n$-butylamine are presented in Table 1 . The substrate specificity of the enzyme was independent of the growth substrate. Highest activities were induced by benzylamine and $n$-butylamine was the most rapidly oxidized substrate. There was no activity with the iso-substituted amines, isopropylamine, 1,2-diaminopropane or isobutylamine.

Crude extracts obtained from organisms grown on benzylamine, $n$-propylamine or $n$-butylamine were subjected to electrophoresis and stained for amine dehydrogenase activity. Regardless of the assay substrate, one band of enzymic activity was detected and was located in an equivalent position in each gel.

\section{Heat stability}

Figure 2 shows the stability of the enzyme after incubation at 55,60 and $65{ }^{\circ} \mathrm{C}$. The enzyme was stable at $55^{\circ} \mathrm{C}$ for 10 min after which there was a decline in activity. At 60 and $65{ }^{\circ} \mathrm{C}$ the amine dehydrogenase activity declined rapidly, $97 \%$ inactivation occurring after incubation for 12 and $3 \mathrm{~min}$, respectively.

\section{Metabolism of benzylamine}

Pseudomonas putida was tested to determine whether proposed intermediates of benzylamine biodegradation would support growth. Benzyl alcohol, benzoate and catechol were 


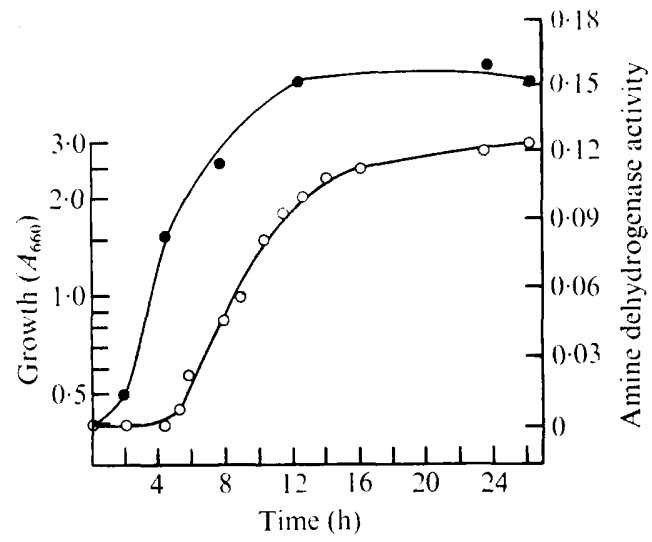

Fig. 1

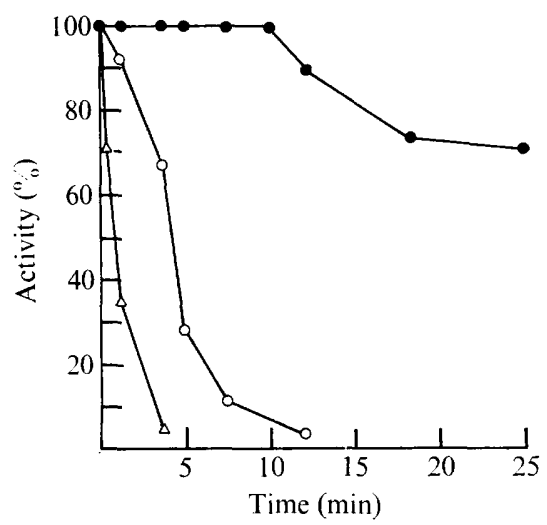

Fig. 2

Fig. 1. Induction of amine dehydrogenase during adaptation of succinate-grown $P$. putida to growth on benzylamine. Washed suspensions of succinate-grown organisms were used to inoculate mineral salts medium containing benzylamine. Growth $(\mathrm{O})$ was measured spectrophotometrically and, at intervals, samples were removed for determination of amine dehydrogenase activity () [expressed as $\mu$ mol DCPIP reduced $\min ^{-1}$ (mg protein) ${ }^{-1}$ ].

Fig. 2. Temperature stability of the amine dehydrogenase from $P$. putidia NP. Samples of enzyme $\left(2.5 \mathrm{mg}\right.$ protein $\left.\mathrm{ml}^{-1}\right)$ were heated in a water bath at $55^{\circ} \mathrm{C}(\bullet), 60^{\circ} \mathrm{C}(\bigcirc)$ or $65^{\circ} \mathrm{C}(\triangle)$ and assayed at intervals for enzymic activity at $24^{\circ} \mathrm{C}$.

utilized, whereas benzaldehyde was not. These four substrates were oxidized by nonproliferating cell suspensions of benzylamine-grown organisms; however, the $Q_{\mathrm{O}_{2}}$ value for benzyl alcohol of $54 \mu 1 \mathrm{O}_{2} \mathrm{~h}^{-1}$ (mg dry wt) ${ }^{-1}$ was less than half the $Q_{\mathrm{o}_{2}}$ values for benzylamine, benzaldehyde, benzoate and catechol, which were $119,160,135$ and $130 \mu \mathrm{l}$ $\mathrm{O}_{2} \mathrm{~h}^{-1}$ (mg dry wt) $)^{-1}$, respectively.

To confirm that benzyl alcohol and benzaldehyde were intermediates in benzylamine biodegradation, the presence of the requisite enzymes was investigated. Benzaldehyde dehydrogenase was induced by growth on benzylamine [specific activity $0.42 \mu \mathrm{mol}$ benzoate $\mathrm{min}^{-1}$ (mg protein $)^{-1}$, but not by growth on benzoate. However, benzyl alcohol dehydrogenase activity was not detected in soluble or particulate fractions of cell extracts after growth of $P$. putida on benzylamine. Benzaldehyde was isolated, as its 2,4-dinitrophenylhydrazone, from the culture medium of benzylamine-grown organisms, and from the reaction mixture resulting from manometric assays of amine dehydrogenase activity in extracts of these organisms. Pseudomonas putida grown on benzylamine or benzoate showed the characteristic yellow colour of 2-hydroxymuconic semialdehyde when incubated with catechol in the cleavage test (Stanier et al., 1966). The specific activity of catechol 2,3-oxygenase in extracts of benzylamine- and benzoate-grown organisms was 0.73 and $0.55 \mu \mathrm{mol}$ product $\mathrm{min}^{-1}$ $(\mathrm{mg} \text { protein })^{-1}$, respectively. There was insignificant catechol 1,2-oxygenase activity $(<0 \cdot 01)$ in extracts of $P$. putida grown on benzylamine.

\section{DISCUSSION}

Little is known about the microbial metabolism of primary monoamines with the exception of methylamine (Anthony, 1975; Quayle, 1972; Ribbons, Harrison \& Wadzinski, 1970) and propylamines (Blevins \& Perry, 1972; Cerniglia \& Perry, 1975). The ability of pseudomonads to utilize amines is well documented (Ballard et al., 1970; Stanier et al., 1966); however, the pathways of carbon assimilation and the enzyme(s) which catalyse the initial oxidative step in amine metabolism in $P$. putida have not been investigated. The observation that cell-free extracts of benzylamine-grown $P$. putida do not consume oxygen except on addition of PMS, suggested that the enzyme responsible for the deamination was not an 
oxidase but an amine dehydrogenase [amine:(acceptor) oxidoreductase (deaminating)]. The ability of DCPIP, PMS, ferricyanide and cytochrome $c$ to function as an electron acceptor was similar to the acceptor specificities of previously reported amine dehydrogenases (Eady \& Large, 1968; Tabor \& Kellogg, 1970).

The absence of amine dehydrogenase activity in organisms grown on succinate or benzoate suggested that the enzyme was inducible. The enzymic specificity of the amine dehydrogenase was independent of the growth substrate. This, together with the equivalent temperature sensitivity of the amine dehydrogenase obtained from benzylamine-, $n$-butylamine- and $n$-propylamine-grown organisms (unpublished data), suggested that the same enzyme was induced by growth on these amines. Polyacrylamide gel electrophoresis of cell extracts yielded one band of enzymic activity, confirming that one enzyme of broad specificity was involved in the deamination of primary amines in $P$. putida NP. Similar results have been reported by Cerniglia \& Perry (1975) for Mycobacterium convolutum.

The substrate specificity of the enzyme was different from that of a methylamine dehydrogenase present in Pseudomonas AM1 (Eady \& Large, 1968), and the rate of oxidation of amines by the enzyme from $P$. putida NP was considerably higher. Neither of these enzymes acts on iso- or tertiary-substituted amines in contrast to an amine dehydrogenase from Mycobacterium convolutum which oxidized isopropylamine (Cerniglia \& Perry, 1975).

The substrate specificity (Table 1) and temperature sensitivity (Fig. 2) of the primary amine dehydrogenase in $P$. putida NP suggest that this enzyme is different from those previously described in Pseudomonas AMl (Eady \& Large, 1968), Methylomonas methylovora (Mehta, 1977), Mycobacterium convolutum (Cerniglia \& Perry, 1975), Serratia marcescens (Tabor \& Kellogg, 1970) and Achromobacter sp. (Satake \& Fujita, 1953).

Pseudomonas putida NP utilized as growth substrates all of the putative intermediates of benzylamine metabolism except benzaldehyde. According to the theory of sequential induction (Stanier, 1947), the results suggested that benzaldehyde, benzyl alcohol, benzoate and catechol may be intermediates in benzylamine degradation. Benzaldehyde dehydrogenase was induced in benzylamine-grown organisms, but benzyl alcohol dehydrogenase was not detected in cell extracts. These data, together with the isolation of benzaldehyde from cell extracts, indicated that benzylamine was deaminated directly to benzaldehyde and subsequently oxidized to benzoate by an inducible benzaldehyde dehydrogenase. The oxidation of benzyl alcohol in whole organisms, not evident in extracts, may be due to a non-specific alcohol dehydrogenase that was not active under our assay conditions.

The conversion of benzoate to catechol proceeded via a benzoate oxidase system, which was measured manometrically in whole organisms grown on benzylamine. In many microorganisms benzoate is converted to catechol through 1,2-dihydro-1,2-dihydroxybenzoic acid via a peroxidation mechanism (Reiner, 1971). Whether a cis-dihydrodiol dehydrogenase was present in cell extracts of benzylamine-grown cells was not determined. However, $P$. putida NP has been previously reported to possess a cis-naphthalene dihydrodiol dehydrogenase following growth on naphthalene (Patel \& Gibson, 1976).

The oxidative cleavage of catechol in pseudomonads occurs by the $\beta$-ketoadipic acid pathway (Stanier \& Ornston, 1973) or by the $\alpha$-keto acid pathway (Dagley et al., 1964; Evans, 1963). The cleavage test (Stanier et al., 1966) to determine which catabolic route was used suggested that 2-hydroxymuconic semialdehyde was formed by both benzoateand benzylamine-grown organisms. Catechol 2,3-oxygenase activity was detected in cellfree extracts indicating that benzylamine and benzoate were metabolized by the meta (or $\alpha$-keto acid) pathway. Pseudomonas putida NP appeared to be similar to P. putida mt-2 (previously designated $P$. arvilla, Murray et al., 1972) in that it metabolized benzoate by the meta pathway, rather than the ortho pathway, which is induced in most benzoate-grown strains of $P$. putida. 
Paper no. 5400 of the Journal Series of the North Carolina Agricultural Experiment Station, Raleigh, North Carolina, U.S.A.

\section{REFERENCES}

ANTHONY, C. (1975). The biochemistry of methylotrophic microorganisms. Science Progress, Oxford 62, 167-206.

BACHRACH, U. (1973). Function of Naturally Occurring Polyamines. New York: Academic Press.

Ballard, R. W., Palleroni, N. J., Doudoroff, M., StaniER, R. Y. \& MANDEL, M. (1970). Taxonomy of the aerobic pseudomonads: Pseudomonas cepacia, $P$. marginata, $P$. alliicola and $P$. caryophylli. Journal of General Microbiology 60, 199214.

Blevins, W. T. \& Perry, J. J. (1972). Metabolism of propane, $n$-propylamine and propionate by hydrocarbon-utılizing bacteria. Journal of Bacteriology 112, 513-518.

Cerniglia, C. E. \& Perry, J. J. (1975). Metabolism of $n$-propylamine, isopropylamine and 1,3-propane diamine by Mycobacterium convolutum. Journal of Bacteriology 124, 285-289.

Dagley, S., Chapman, Y. J., Gibson, D. T. \& Wood, J. M. (1964). Degradation of the benzene nucleus by bacteria. Nature, London 202, 775-778.

Dahl, J. S., Mehta, R. J. \& Hoare, D. S. (1972). New obligate methylotroph. Journal of Bacteriology 109, 916-921.

Davis, B. J. (1964). Disc electrophoresis. II. Methods and application to human serum proteins. Annals of the New York Academy of Sciences 121, 404 427.

Durham, D. R. \& PerRy, J. J. (1977). Characterization of an inducible amine dehydrogenase from Pseudomonas putida. Abstracts of the Annual Meeting of the American Society for Microbiology, p. 177.

EADY, R. R. \& LaRge, P. J. (1968). Purification and properties of an amine dehydrogenase from Pseudomonas AMl and its role in growth on methylamine. Biochemical Journal 106, 245-255.

Evans, W. C. (1963). The microbial degradation of aromatic compounds. Journal of General Microbiology 32, 177-184.

Feist, C. F. \& Hegeman, G. D. (1969). Phenol and benzoate metabolism by Pseudomonas putida: regulation of tangential pathways. Journal of Bacteriology 100, 869-877.

Hegeman, G. D. (1966). Synthesis of the enzymes of the mandelate pathway by Pseudomonas putida. I. Synthesis of enzymes of the wild type. Journal of Bacteriology 91, 1140-1154.

KAPEller-AdLer, R. (1970). Amine Oxidases and Methods for Their Study. New York: WileyInterscience.

LAEMMLI, U. K. (1970). Cleavage of structural proteins during the assembly of the head of bacteriophage $\mathrm{T}_{4}$. Nature, London 227, 680-685.
LARGE, P. J. (1971). The oxidative cleavage of alkylnitrogen bonds in microorganisms. Xenobiotica 1, 457-467.

Leadbetter, E. R. \& FosteR, J. W. (1958). Studies on some methane-utilizing bacteria. Archiv für Mikrobiologie 30, 91-118.

Lowry, O. H., Rosebrough, N. J., FARR, A. L. \& Randall, R. J. (1951). Protein measurement with the Folin phenol reagent. Journal of Biological Chemistry 193, 265-275.

MentA, R. J. (1977). Methylamine dehydrogenase from the obligate methylotroph Methylomonas methylovora. Canadian Journal of Microbiology 23, 402-406.

Murray, K., Duggleby, C. J., Sala-Trepat, J. M. \& Williams, P. A. (1972). The metabolism of benzoate and methylbenzoates via the metacleavage pathway by Pseudomonas arvilla mt-2. European Journal of Biochemistry 28, 301-310.

Patel, T. R. \& Gibson, D. T. (1976). Bacterial cisdihydrodiol dehydrogenases: comparison of physicochemical and immunological properties. Journal of Bacteriology 128, 842-850.

QUAYLE, J. R. (1972). The metabolism of one-carbon compounds by microorganisms. Advances in Microbial Physiology 7, 119-203.

ReINER, A. M. (1971). Metabolism of benzoic acid by bacteria: 3,5-cyclohexadiene-1,2-diol-1-carboxylic acid is an intermediate in the formation of catechol. Journal of Bacteriology 108, 89-94.

Ribions, D. W., Harrison, J. E. \& Wadzinski, A. M. (1970). Metabolism of single carbon compounds. Annual Review of Microbiology 24, 135158.

Satake, K. \& Fujita, H. (1953). Studies on amine dehydrogenases. I. Bacterial histamine and putrescine dehydrogenases. Journal of Biochemistry 40, 547-556.

Stanier, R. Y. (1947). Simultaneous adaption: a new technique for the study of metabolic pathways. Journal of Bacteriology 54, 339-348.

Stanier, R. Y. \& Ornston, L. N. (1973). The $\beta$ ketoadipate pathway. Advances in Microbial Physiology 9, 89-151.

Stanier, R. Y., Palleroni, N. J. \& Doudoroff, M. (1966). The aerobic pseudomonads: a taxonomic study. Journal of General Microbiology 43, 159271.

TABor, C. W. \& KellogG, P. D. (1970). Identification of flavin adenine dinucleotide and heme in a homogeneous spermidine dehydrogenase from Serratia marcescens. Journal of Biological Chemistry 245, 5424-5433.

Umbreit, W. W., Burris, R. H. \& Stauffer, J. F. (1964). Manometric Techniques, 4th edn. Minneapolis: Burgess Publishing Co. 